\title{
POOR DOGSBODY, POOR DOGSBODY'S BODY
}

\author{
- for John Travolta
}

Not strayed, but leashed.

The service truck coming at the dogs across the tarmac, the actor emerging from his jet, whistling, waving, the deathyelp, the German Shepherd chasing my brother, the more than a million stray dogs roaming the streets of Baghdad, the airline apologizing through their spokesperson (we regret to inform you, a matter of unfortunate circumstance, couldn't we just buy you another), the actor demanding something be done, the neighborhood children shouting, I couldn't tell, at my brother or the dog, the man telling reporters, "I wish they would kill all the dogs because they are harmful, they carry diseases and I'm afraid for my children," the shouts that come from among the paparazzi gathered at the Bangor airport, the actor trying, without success, to shield their bodies, the part of his ass where the teeth had gone through, four red wells of blood, the two shooters and two vets assigned to either shoot or poison the dogs and then dump them on slag heaps, the reports of the "freak accident," the actor alleging premeditation or negligence at best, the owner pulling the German Shepherd away, crying, calling its name (Salaam, Salaam), the refuse and waste strewn throughout Baghdad's streets, the dogs that are drawn to it, the dogs already there.

Not mourn, but cull. 